\title{
Skill-biased technical change: on endogenous growth, wage inequality and government intervention
}

Citation for published version (APA):

Hollanders, H. J. G. M., \& ter Weel, B. J. (1999). Skill-biased technical change: on endogenous growth, wage inequality and government intervention. MERIT, Maastricht Economic Research Institute on Innovation and Technology. MERIT Research Memoranda No. 013 https://doi.org/10.26481/umamer.1999013

Document status and date:

Published: 01/01/1999

DOI:

10.26481/umamer.1999013

Document Version:

Publisher's PDF, also known as Version of record

\section{Please check the document version of this publication:}

- A submitted manuscript is the version of the article upon submission and before peer-review. There can be important differences between the submitted version and the official published version of record.

People interested in the research are advised to contact the author for the final version of the publication, or visit the DOI to the publisher's website.

- The final author version and the galley proof are versions of the publication after peer review.

- The final published version features the final layout of the paper including the volume, issue and page numbers.

Link to publication

\footnotetext{
General rights rights.

- You may freely distribute the URL identifying the publication in the public portal. please follow below link for the End User Agreement:

www.umlib.nl/taverne-license

Take down policy

If you believe that this document breaches copyright please contact us at:

repository@maastrichtuniversity.nl

providing details and we will investigate your claim.
}

Copyright and moral rights for the publications made accessible in the public portal are retained by the authors and/or other copyright owners and it is a condition of accessing publications that users recognise and abide by the legal requirements associated with these

- Users may download and print one copy of any publication from the public portal for the purpose of private study or research.

- You may not further distribute the material or use it for any profit-making activity or commercial gain

If the publication is distributed under the terms of Article $25 \mathrm{fa}$ of the Dutch Copyright Act, indicated by the "Taverne" license above, 


\title{
Skill-Biased Technical Change: On Endogenous Growth, Wage Inequality and Government Intervention*
}

\author{
Hugo Hollanders ${ }^{\mathrm{a}}$, Bas ter Weel ${ }^{\mathrm{a}, * *}$ \\ ${ }^{a}$ Maastricht Economic Research Institute on Innovation and Technology (MERIT), \\ Maastricht University, Maastricht, the Netherlands
}

\begin{abstract}
This paper builds a general equilibrium model of endogenous growth outside the representative agent framework to show that when individuals are heterogenous, persistent inequality will be the result of economic growth. Individuals are assumed to be born with different abilities, which will lead to a steady state growth path of biased technical change towards individuals with a higher ability. The problem of inequality as a result of skill-biased technical change is partially solved by allowing for government intervention. Intervention is shown to solve the problem to such a degree that particular subsidies and taxes on labor income are efficient.
\end{abstract}

Keywords: Growth; Government intervention; Human capital; Skill-biased technical change

JEL Classification: O30; O38; J24

\footnotetext{
* An earlier version of this paper was presented at MERIT (Hollanders and Ter Weel, 1998). We gratefully acknowledge Robin Cowan, Huub Meijers, Pierre Mohnen, Luc Soete, Thomas Ziesemer and Adriaan van Zon for helpful and useful comments on an earlier draft of this paper. Of course the usual disclaimer applies.

** Corresponding author. Maastricht Economic Research Institute on Innovation and Technology (MERIT), Maastricht University, P. O. Box 616, 6200 MD, Maastricht, the Netherlands, Tel: 0031-43-3883873, Fax: 0031-433216518, E-mail: b.terweel@merit.unimaas.nl.
} 


\section{Introduction}

The contemporary debate on the causes and consequences of skill-biased technical change has been documented econometrically and empirically for many countries in recent years. The direction of the explanations differs widely from trade with low-wage countries (Wood, 1998) and trade between the US and the European Union countries (Davis and Reeve, 1997) to simply 'blaming' technical change (Krugman, 1995). However, solutions to the problem are not offered very often and are mostly not considered in a thorough manner. The OECD (1998) for example only states that investment in human capital and upgrading of skills will offer a solution to the weak position of low-skilled workers in its member countries without specifying specific action.

This paper is based on some recent work (Acemoglu, 1998 and Hollanders and Ter Weel, 1998) and considers in a theoretical fashion the consequences of skill-biased technical change by modeling technical change in such a manner that skilled workers profit relatively more from the technical advancement than unskilled workers. This is done by elaborating first on the insights in the literature available in this particular field in economics and then by building a model to explain and explore skill-biased technical change. The way of modeling skill-biased technical change applied here has recently been applied by Acemoglu (1998) and is referred to by him as 'directed technical change'. However, Acemoglu uses only two types of skills: skilled and unskilled workers. Moreover, his model is not able to give general equilibrium properties in a long-run steady-state solution, which are necessary to develop policy measures to solve the problem. The approach developed in this paper considers a general equilibrium model with heterogenous labor in a continuum of skills ranging from no skills to a certain 'maximum level' of skills. The heterogeneity of the individuals populating this economy does already exist upon birth, i.e. every individual is born with some ability or talent which can be developed during his life. This framework is discussed in terms of a dynamic approach to the changing skills profile over time.

Firms in this economy divide their time between investing in knowledge creation to enhance their product and production process (it is assumed that there is only one product in this economy) as to become more efficient and in that way obtain a higher level of profits. Firms employ labor and 
of course prefer relatively skilled labor over relatively unskilled labor. This provides a positive feedback loop of investment decisions which gives individuals an incentive to invest in human capital, since more products or more advanced products go hand in hand with a higher level of lifetime utility.

The framework considered makes it relatively more complex to model the exact implications of technical change for different groups in society because it steps outside the representative agent framework. However, despite this complexity the model provides a more realistic picture of the dilemmas and problems governments face to come up with a solution for this perturbing problem of inequality.

The plan of this paper is the following. First an overview is given of the literature on the different kinds of technology and technical change used in several contributions by a wide variety of scholars in the field of economic growth. This is linked to the debate on skill-biased technical change is such a manner that it gives a clear picture of the different explanations of skill-biased technical change. In the third section a model of skill-biased technical change is build and explored. Section 4 discusses optimal government policy along the lines of the framework and conclusions developed in Section 3. This paper ends with some concluding remarks. 


\section{Overview of the Literature on Skill-Biased Technical Change and Technology}

The literature on technical change is already considered in an elaborate manner many times. E.g. Aghion and Howitt (1998a) provide an overview and extensions of the Schumpeterian insights formalized in new growth theory, which is initiated in Nelson and Winter (1982) and Dosi, Freeman, Nelson, Silverberg and Soete (1988). Segerstrom, Anant and Dinopoulos (1990) provide in this regard a model of sustained growth as arising from a succession of product improvements and Aghion and Howitt (1998a) based on Aghion and Howitt (1992) show a wide variety of growth paths through 'creative destruction' in both goods and labor markets and are able to describe the process of innovation and (human) capital accumulation in a comprehensive manner. Barro and Sala-i-Martin (1995) provide both a theoretical and empirical approach to the early Solow-Swann models of exogenous growth to the modern theories of endogenous growth. Schneider and Ziesemer (1995) provide in this regard a richer analysis of the theoretical models of growth. These authors consider a wide variety of views on the growth process ranging from the Solow-Swann model and the pioneering contribution of Arrow (1962) to the evolutionary models brought together in Dosi et al. (1988). Harberger's 'vision of the growth process' is determined by considering many empirical studies and estimating total factor productivity in many sectors. His approach rests on five pillars of growth: (i) the rate of increase in the stock of human capital; (ii) the increase in the capital stock; (iii) the rate of return which that investment will yield; (iv) the rate of increase in the labor force; and (v) real cost reductions stemming from many different sources (Harberger, 1998). Lucas (1993) introduces a growth puzzle of the Philippines and South Korea in which differences in schooling and technology policy might be explanatory variables as to how, given the nearly identical starting points, it is possible that South Korea 'made a miracle', on average annual GDP per capita grew by $6 \%$, while the Philippines stagnated at about $2 \%$. He finds the answer in a neoclassical framework with a strong focus on technology, while Bénabou (1996) suggests that the answer to the puzzle may lie outside the representative agent framework by noting that the Gini-coefficient was much higher in the Philippines than in South Korea indicating that initial inequality has negative effects on the performance of a country. Hollanders and Ter Weel (1999), following Azariadis and Drazen (1990) and Redding (1996), suggest that the Philippines might be caught in a low-development trap, while South Korea observed a high-development path over the past decades. Higher levels 
of technology policy and more advanced schooling methods might be an answer as to why South Korea grew so fast, while the Philippines observed a relatively low rate of economic growth. ${ }^{1}$ Finally, Verspagen (1992), in his review of new growth theory, pays special attention to the role of government in the process of economic growth. He concludes that the role of the government is poorly represented in most of the models on endogenous growth. Romer (1993), Weder and Grubel (1993) and Soete and Ter Weel (1999) provide in this regard strong cases for the implementation of technology policies to enhance innovation and economic growth.

Starting from Arrow (1962), the ancestor in the founding works of endogenous growth theory, economists have formalized and endogenized neoclassical growth theory based on two factors: capital and homogenous labor. However, the channels through which this should be achieved differ widely. In addition the measures of technology show a diverse pattern too. Arrow (1962), King and Robson (1993), Stokey (1988), Yang and Borland (1991) and Young (1991), (1993a) and (1993b) all use learning by doing. Grossman and Helpman (1989) and (1991a) and Judd (1985) use new varieties of consumer goods, whereas Aghion and Howitt (1992) and (1998a), Grossman and Helpman (1990) and (1991b) and Romer (1987) and (1990) use new varieties of factors. Intergenerational technology transfers are used as a content of technology by Prescott and Boyd (1987) whereas Becker, Murphy and Tamura (1990) and Rebelo (1991) use household's knowledge; firm's knowledge is used in Ziesemer (1991). Lucas (1988) and Romer (1986) use private knowledge spillovers in their endogenous growth models, while Acemoglu (1998) and (1999) and Goldin and Katz (1998) point towards capital-skill complementarity inducing technical change. Finally, Helpman and Trajtenberg (1998a) and (1998b) track the effects of a new General Purpose Technologies (GPTs) on macroeconomic aggregates and consider the process of a new GPT diffusion. The main finding of the approach is a view of the growth process in which the notion of increasing returns underlying new growth theory can be explained by the fostering complementary advances induced by new GPTs. Aghion and Howitt (1998b) and Howitt (1998) argue that the Helpman-Trajtenberg-model is incomplete and introduce social learning into the model. Harris (1998) by applying the theoretical framework of GPTs to the Internet, finds that, due to the introduction of the Internet, virtual mobility of mostly skilled

\footnotetext{
${ }^{1}$ See for an elaboration on and alternative explanations of Lucas' growth puzzle and the factors underlying the growth performance in more than 200 countries Hollanders, Soete and Ter Weel (1999, Part C).
} 
labour increases resulting in a wage premium to skilled labour. Murphy, Riddell and Romer (1998) investigate this result empirically for Canada and the US and conclude that new GPTs are relative complements with more educated labour, which is closely related to the thesis that machinery and new technologies harm low-skilled workers. Rosenberg (1998) suggests that the notion of a GPT has to be broadened to include intellectual methodologies, such as in chemical engineering, which may bring to the forefront valuable new insights into the underlying determinants of technical change and the diffusion of GPTs. Lipsey, Bekar and Carlaw (1998a) and (1998b) focus on the consequences of changes in GPTs by particularly stressing the debate between the Helpman-Trajtenberg and Aghion-Howitt-model. By building a structuralist model, including alongside the neo-classical components technology and policy variables, they argue that it is the structure of technology systems which should be focussed on. According to these authors structural issues are the core of an understanding of growth as driven by technical change. Bresnahan and Gambardella (1998) examine the division of inventive labour and the extent of the market. They endogenize the arrival of GPTs, which was assumed to be exogenous in the models of Helpman and Trajtenberg and Aghion and Howitt. They find a self-enforcing loop of inventions induced by increasing specialization of knowledge and diverse markets in which new GPTs continue to contribute to growth, and most importantly that growth continues to permit their invention.

This and other notions have led to the fact that the economic's profession recognized that when new technologies are introduced in the production process, or when technical change is incorporated in an economic model, this reduces the demand for low-skilled labor relative to the demand for high-skilled labor. In general the rationale for this argument is that high-skilled labor and capital are complements, whereas high-skilled labor and low-skilled labor are substitutes, e.g. many routine assembly activities are replaced. In Griliches' pioneering contribution (Griliches, 1969) this complementarity is due to the relative decline of the price of capital, while Denny and Fuss (1983) attribute this issue to the specific effects of technical changes. Murphy, Riddell and Romer (1998) discuss it empirically for Canada and the US. Their conclusion is that new technologies are relative complements with more educated labor. From this perspective, as noted recently in a growth model by Acemoglu (1998) and investigated in a historical perspective by Goldin and Katz (1998), human capital and technology are two faces of the same coin, two 
non-separable aspects of knowledge accumulation. Finally, it is acknowledged that high-skilled workers adapt more easily to changing technologies than their low-skilled colleagues; e.g. the computer revolution increases the productivity of high-skilled workers more than the productivity of low-skilled workers, leading to wage dispersion. ${ }^{2}$

This idea is obviously closely related to the discussions on skill-biased technical change and (wage) inequality - cf. Juhn, Murphy and Pierce (1993). Since a higher proportion of skilled workers in the labor force implies a large market for high-skilled technology, an increase in the supply of skills induces skill-biased technical change, as a result of the employment of these skilled workers, despite rising relative wages. ${ }^{3}$ In the econometric literature concerning the impact of technical change on employment and wages, much evidence has been brought together highlighting the reduction of the demand for low-skilled labor relative to the demand for highskilled labor.

The debate on the wage premium on skills and knowledge due to new technologies at the individual level has been initiated by an influential study of Krueger (1993), but the evidence from several studies is not conclusive. Krueger shows that in the US the use of computers brought the workers surveyed a wage premium of some $15 \%$. Such a premium could be attributed either to an increase in productivity or to user's personal characteristics, which led them in all cases to receive significantly higher wages. Krueger favors the first explanation, even though cross-section data did not allow for such conclusions to be drawn. By contrast, Entorf and Kramarz (1997) show for France that workers using computers did already receive a higher wage before they started using one. Moreover, DiNardo and Pischke (1997) - in a critical assessment of Krueger's results - observe for Germany that the use of pencils has a similar effect on the wage rate as computer use has. Only Bell (1996), using a sample of one thousand individuals finds a net increasing effect on wages for those using computers at work. Other empirical work carried

\footnotetext{
${ }^{2}$ Acemoglu (1999) enters this debate by referring to the impact of international trade on wage inequality, while Wood (1998) and Francois and Nelson (1998) refer to the increasing effects of globalization and the subsequent new opportunities for trade as a major cause of (wage) inequality.

${ }^{3}$ See e.g. Berman, Bound and Machin (1998) and Machin and Van Reenen (1998) for recent empirical evidence in this regard and Acemoglu (1998) and (1999) and Aghion and Howitt (1998a) for an elaborate theoretical framework.
} 
out by e.g. Baldwin, Divery and Johnson (1995) for Canada, Bellman and Boeri (1995) for Germany, Vainiomaki and Laaksonen (1995) for Finland, Entorf and Kramarz (1997) for France, Bruinshoofd and Ter Weel (1998) and Bruinshoofd, Hollanders and Ter Weel (1999) for the Netherlands, Chennells and Van Reenen (1997) and Hildreth (1998) for the UK and Bound and Johnson (1992), Doms, Dunne and Troske (1997) and Juhn, Murphy and Pierce (1993) for the US find that there exists in general a technology wage premium. ${ }^{4}$ However, the measures of technology differ widely and it is therefore hard to compare the results of all these studies.

This overview points towards the importance of the complementarity of skill accumulation and technical change, indicating a particular direction of technical change. The remainder of this paper builds an endogenous growth model to show the effects of skill-biased technical change on wages and its consequences on the wage distribution.

\footnotetext{
${ }^{4}$ See also e.g. Autor, Katz and Krueger (1998), Bartel and Sicherman (1995), Heckman, Lochner and Taber (1998), Heckman and Sedlacek (1985), Katz and Murphy (1992), Meghir and Whitehouse (1996) and Nickell and Bell (1995) and (1996).
} 


\section{A Model of Skill-Biased Technical Change}

Consider a closed economy with competitive markets populated by a large number of heterogenous Ramsey consumers. These consumers have standard, discounted, constant elasticity preferences resulting in the following utility function

$$
U_{t, s}=\frac{C_{t, s}^{1-\sigma}-1}{1-\sigma} e^{-\rho t}
$$

where the discount rate $\rho$ and the coefficient of relative risk aversion $\sigma$ are both strictly positive. $C_{t, s}$ is defined as the amount of consumption of person $i$ with skill level $s$ at time $t$. The skill level $s$ is assumed to be uniformly distributed over a range $\left[s_{0}, s_{1}\right]$. Moreover, every individual in this economy has a different skill level, which can be viewed as the ability this individual is born with at time $t=0$. Hence, for each skill level there exists only one individual. ${ }^{5}$

Capital accumulation is defined as net income minus consumption:

$$
\dot{K}_{t, s}=(1-\tau) r_{t} K_{t, s}+(1-\tau) w_{t}\left(1-u_{s}\right) H_{t, s}-C_{t, s}
$$

where $\tau$ is a capital income tax for both physical and human capital, $r_{t}$ is the return on physical capital $K_{t, s}$ at time $t, w_{t}$ the return on human capital $H_{t, s}$, and $u_{s}$ is the amount of time spent to acquire additional human capital; $\left(1-u_{s}\right)$ is the amount of time spent to produce output. This budget constraint implies that all wealth generated - or all savings - is immediately transformed into physical capital.

Accumulation of human capital is assumed to be skill-biased since individuals with a higher skill level profit more from technical progress than individuals with a lower level of skills. Acemoglu

\footnotetext{
${ }^{5}$ Most models in the literature divide the labor force in a skilled and unskilled segment, following the properties first stated in McDonald and Solow (1986). The results of these approaches are often crowding-out of unskilled labor due to the fact that unskilled labor and capital are substitutes while skilled labor and capital are assumed to complement each other. The latter induces an engine of growth which leads to a large dispersion in wages and results in inequality in society.
} 
(1998) and (1999) refers to this fact as 'directed technical change' in favor of skilled labor. Equation (3) states that individuals with a higher skill level profit exponentially from an increase in technical progress $A_{t}$

$$
\dot{H}_{t, s}=A_{t}^{s} u_{s} H_{t, s}^{\beta} B_{t}^{\gamma}-\mu H_{t, s}
$$

with $0<\beta<1$ and $0 \leq s \leq 1 . u_{s}$ is the time spent to accumulate human capital and $\mu$ is the exogenous rate of depreciation of human capital. Throughout this paper however, no depreciation of skills or human capital is assumed, i.e. $\mu=0 . B_{t}$ is knowledge provided publicly by the government, whereas $A_{t}$ is provided privately as a result of the R\&D process firms are engaged in, and it is assumed that no public action is taken to directly influence the supply of private knowledge. The stock of public knowledge is enhanced at some costs collected by the government in the form of capital income taxes $\tau$ - cf. equation (2).

Now, maximizing utility, subject to the budget constraint defined by equation (2) and human capital accumulation as in equation (3), leads to the following Hamiltonian

$$
\Omega=\left(\frac{C_{t, s}^{1-\sigma}-1}{1-\sigma}\right) e^{-\rho t}+\lambda_{1}\left(A_{t}^{s} u_{s} H_{t, s}^{\beta} B_{t}^{\gamma}-\mu H_{t, s}\right)+\lambda_{2}\left((1-\tau) r_{t} K_{t, s}+(1-\tau) w_{t}\left(1-u_{s}\right) H_{t, s}-C_{t, s}\right)
$$

Solving this problem results in a standard Euler equation for individual $i$ with skill level $s$ :

$$
\hat{C}_{t, s}=\frac{(1-\tau) r-\rho}{\sigma}
$$

where the after-tax return on capital (1- $\tau) r$ is assumed to exceed the discount rate $\rho$. In the steady state the rental rate $r$ has to be constant because the growth of the marginal product of capital equals zero by definition. Appendix A provides the mathematical proof for these results and properties.

Optimizing with respect to $H_{t, s}$ yields the growth rate of human capital which depends both on the growth rates of private and public knowledge accumulation, $A_{t}$ and $B_{t}$, respectively: 


$$
\hat{H}_{t, s}=\frac{s \hat{A}_{t}+\gamma \hat{B}_{t}}{1-\beta}
$$

Equation (5) is of central importance to our analysis because this equation shows that public knowledge accumulation adds an unbiased amount of human capital to the individual's existing human capital stock. This equation also indicates that private human capital accumulation is biased and depends on the skill level $s$ an individual incorporates.

In order to compute the overall level of human capital we must add up all individuals. Since the impact of skills is normalized, Appendix B shows that this leads to

$$
H_{t}=\int_{0}^{1} H_{t, s} d s=\frac{(1-\beta)\left[e^{\left(\hat{A}_{t}+\gamma \hat{B}_{t} t t /(1-\beta)\right.}-e^{\left(\gamma \hat{B}_{t}\right) t /(1-\beta)}\right]}{t \hat{A}_{t}}
$$

Now, some straightforward algebra show that the steady state growth rate of the overall level of human capital converges to

$$
\lim _{t \rightarrow \infty} \hat{H}_{t}=\frac{\hat{A_{t}+\gamma \hat{B}_{t}}}{1-\beta}
$$

which is equal to the growth rate of human capital of the individual with the highest ability $s=1$. This result indicates that the skill bias increases because less and less individuals embody more and more human capital. The recognition of the importance of the notion of knowledge accumulation is challenging not only the traditional focus on the R\&D process, but the whole spectrum of scientific and technical activities from invention to diffusion, from basic research to technical mastery. Such a view of technical change rejects the definition of technical capabilities in terms of knowledge or information with the connotation that industrial technology is like a recipe; understood by particular individuals and readily articulatable and communicable from one individual to another with the requisite background training and skills. Knowing how to produce a product, is as much experienced 'tacit skill' as articulatable knowledge. Contrary 
to the implicit general theory, skills of a skilled worker in the art are not interchangeable: who works with the recipe makes a difference. Therefore, training new workers has become much more expensive when one takes these arguments into account and the human capital employed by firms will increasingly be embodied in less skilled individuals, thereby further increasing the gap between skilled an unskilled workers. ${ }^{6}$

The government collects capital income taxes $(\tau)$ on both human and physical capital to finance the accumulation of public knowledge. This can be expressed as follows:

$$
\dot{B}_{t}=\tau r K_{t}+\tau w_{t}\left(\int_{0}^{1}\left(1-u_{s}\right) H_{t, s} d s\right)
$$

Public knowledge is invested in the accumulation of human capital as can be observed from equation (3). The intention and main objective of the government is to distribute income and therefore implicitly human capital more equally. However, the collection of additional capital income taxes has both a positive and negative effect. Since the taxes are used to stimulate the level of the public knowledge available it has a positive effect on overall productivity. On the other hand, additional capital income taxes have a negative effect on the private accumulation of physical and human capital, as shown below.

Firms allocate human capital between final goods production and technology production. Using $(1-\phi)$ of the human capital stock available to the firm, they produce output $Y_{t}$ using a standard increasing returns-to-scale Cobb-Douglas production function with labor saving technical change:

$$
Y_{t}=K_{t}^{\alpha}\left(A_{t} \int_{0}^{1}\left((1-\phi)\left(1-u_{s}\right)\right) H_{t, s} d s\right)^{v}
$$

\footnotetext{
${ }^{6}$ Moreover, this trend can also induce a sector bias in technical change, since some sectors might have more resources and scope to invest in knowledge, both codified and tacit, which can lead to large differences in the accumulation of tacit knowledge, inducing an absorbing effect on high-skilled labor from other sectors - cf. Bruinshoofd and Ter Weel (1998) and Haskel and Slaughter (1998) for one of the initial empirical assessments of the sector bias of technical change.
} 
where $0<\phi<1, \alpha>0, v>0$ and $\alpha+v=1$. Firms dedicate $\phi$ of their available human capital stock to enhance technical progress, i.e.

$$
\dot{A_{t}}=\left(\int_{0}^{1}\left(\phi\left(1-u_{s}\right)\right) H_{t, s} d s\right)^{\delta} A_{t}^{\xi}
$$

where $0<\delta<1,0<\xi<1$ and $\delta+\xi<1$. The latter restriction is in line with empirical findings that show that the growth predictions of traditional models of Uzawa (1965) and Romer (1986) with $\delta=\xi=1$, contradict post-war growth experiences, investigated by Jones (1995b), of the major OECD countries. This is confirmed by the steady-state solution for $\phi$ which shows that the traditional specification $\delta=\xi=1$ can be ruled out (see equation (C.10) in appendix C). Furthermore, the restriction that the production of technology exhibits decreasing returns-to-scale is imposed. ${ }^{7}$

Firms then maximize profits according to the following Hamiltonian:

$$
\Pi=K_{t}^{\alpha}\left(A_{t} \int_{0}^{1}\left((1-\phi)\left(1-u_{s}\right)\right) H_{t, s} d s\right)^{v}-r K_{t}-w_{t} \int_{0}^{1}\left(1-u_{s}\right) H_{t, s} d s+\lambda_{3}\left(\int_{0}^{1}\left(\phi\left(1-u_{s}\right)\right) H_{t, s} d s\right)^{\delta} A_{t}^{\xi}
$$

Defining $H_{t, f}$ as

$$
\int_{0}^{1}\left(1-u_{s}\right) H_{t, s} d s
$$

and taking partial derivatives, with respect to the control variables $K_{t}, H_{t, f}$ and $\phi$, and the state variable $A_{t}$, yield the following expressions for the growth rate of the physical and human capital stock available to the firm and the stock of private knowledge (see Appendix C and D for proof):

\footnotetext{
${ }^{7}$ Jones (1995a) imposes the restriction $\xi<1$ and shows that this leads to a model in which a balanced growth path is consistent with an increasing number of persons devoted to technology production.
} 


$$
\begin{gathered}
\hat{K}_{t}=\left(\frac{(1+\delta-\xi)}{\delta}\right) \hat{A}_{t} \\
\hat{H}_{t, f}=\left(\frac{(1-\xi)}{\delta}\right) \hat{A}_{t} \\
\hat{K}_{t}=\hat{C}_{t}
\end{gathered}
$$

The restriction $\delta+\xi<1$ ensures that the growth rate of the physical capital stock in equation (11) is positive. An increase in $\xi$ and $\delta$, the effectiveness of private knowledge respectively human capital in the production of private knowledge, has a positive effect on the growth rates in equations (11) and (12).

Using equations (11) - (13) the outcomes for the growth rates of $K_{t}, H_{t}$ and $A_{t}$ can be re-expressed in the parameters of the model. This results in equations (14) - (16):

$$
\begin{gathered}
\hat{C}_{t}=\hat{K}_{t}=\frac{(1-\tau) r-\rho}{\sigma} \\
\hat{H}_{t}=\frac{(1-\xi)[(1-\tau) r-\rho]}{(1-\xi+\delta) \sigma} \\
\hat{A}_{t}=\frac{\delta[(1-\tau) r-\rho]}{(1-\xi+\delta) \sigma}
\end{gathered}
$$

From these three equations, and already pointing to the discussion in the next section, it can be observed that capital income taxes have a negative effect on the growth rate of all three variables. The rationale is intuitively straightforward and consistent with the fact that negative externalities have negative effects on growth rates. 
Formally, equations (14) - (16) can be examined by investigating the effects of each of the exogenous parameters in the growth rates of $K_{t}, H_{t}$ and $A_{t}$ in the following table.

Table 1: Investigating Equations (14) - (16)

\begin{tabular}{cccc}
\hline & $\partial \hat{K}_{t}$ & $\partial \hat{H}_{t}$ & $\partial \hat{A}_{t}$ \\
\hline$\partial r$ & $>0$ & $>0$ & $>0$ \\
$\partial \rho$ & $<0$ & $<0$ & $<0$ \\
$\partial \sigma$ & $<0$ & $<0$ & $<0$ \\
$\partial \xi$ & - & $<0$ & $>0$ \\
$\partial \delta$ & - & $<0$ & $>0$ \\
\hline
\end{tabular}

In the next section we explore these results and show how the skill bias due to the bias in private human capital accumulation, as a result of dispersion in abilities, can be reduced by government intervention. 


\section{Government Intervention Reducing the Bias in Skill Accumulation}

Firm-specific innovations are induced and occur because of the effort of the firm's research department on the one hand, and public knowledge from the 'public basin' on the other hand. Public knowledge is enhanced by research performed at universities and other research institutes financed by the government through variable $B_{t}$. Their output in the form of knowledge is often published in scientific journals or transmitted by channels such as conferences. This improves the overall knowledge stock in the economy in an unbiased way and induces innovative activities. As proven above, firms increase labor productivity levels in a skill-biased manner which in turn lead to higher levels of innovative activities in the research department and higher levels of production in the manufacturing division.

Equation (5) implies that in the long run or steady state individuals with a higher ability experience a higher growth rate of human capital. The dispersion in levels of human capital between high and low-skilled individuals thus increases over time. Hence, the need for government intervention to deal with this dispersion is valid and necessary.

In this section a partial equilibrium analysis is performed on several variables in the model. First, it can be shown that technical progress originating in the private sector leads to an increase in the efficiency of human capital production biased towards individuals with higher initial abilities. This can be shown by investigating a case in which there are two individuals with abilities $s_{i}$ and $s_{j}$, where $s_{i}>s_{j}$. Using equation (5) the set up of this problem can be shown by the following expression:

$$
\frac{\hat{H}_{s_{i}}}{\hat{H}_{s_{j}}}=\frac{s_{i} \hat{A}_{t}+\gamma \hat{B}_{t}}{s_{j} \hat{A}_{t}+\gamma \hat{B}_{t}}
$$

From this expression for two different levels of skills it can be easily observed that an increase in the growth rate of private knowledge $A_{t}$ leads to a biased increase in the growth rate of the ratio of human capital, i.e. the ratio $\hat{H}_{s i} / \hat{H}_{s j}$ increases. This means that the relatively skilled individual (the individual with skill level $s_{i}$ ) profits more from this enhancement in the 
accumulation of private knowledge than the relatively unskilled individual (the individual with skill level $s_{j}$ ). More formally:

$$
\frac{\partial\left(\hat{H}_{s_{i}} / \hat{H}_{s_{j}}\right)}{\partial \hat{A}_{t}}=\frac{\left(s_{i}-s_{j}\right) \gamma \hat{B}_{t}}{\left(s_{j} \hat{A}_{t}+\gamma \hat{B}_{t}\right)^{2}}>0
$$

With respect to government intervention, the opposite result can be obtained. As is defined above, government intervention by means of a capital income tax $\tau$ hurts relatively skilled labor more than relatively unskilled labor because the tax is on the income of both physical and human capital income. Physical capital is assumed to be distributed equally, but human capital not. Therefore, an increase in public knowledge, financed by an increase in capital income taxes has a positive effect on the individual with skill level $s_{j}$ relative to the individual with skill level $s_{i}$. Hence, it can be shown in a more formal way, that an increase in the growth rate of public knowledge leads, ceteris paribus, to a relative increase in the growth rate of the unskilled individual's human capital:

$$
\frac{\partial\left(\hat{H}_{s_{i}} / \hat{H}_{s_{j}}\right)}{\partial \hat{B}_{t}}=\frac{\left(s_{j}-s_{i}\right) \gamma \hat{A}_{t}}{\left(s_{j} \hat{A}_{t}+\gamma \hat{B}_{t}\right)^{2}}<0
$$

Focusing on the short run, these effects can best be studied by investigating level effects of relative skill embodiment instead of growth rates. Again assuming two individuals with skill level $s_{i}$ and $s_{j}$, where $s_{i}>s_{j}$, the relative level of human capital can be expressed in natural logarithms, using equation (5), as follows

$$
\ln \left(\frac{H_{t, s_{i}}}{H_{t, s_{j}}}\right)=\frac{\left(s_{i}-s_{j}\right)[(1-\tau) r-\rho] \delta t}{(1-\xi+\delta)(1-\beta) \sigma}
$$

This expression leads to the following proposition: 
PROPOSITION 1: Relative dispersion in the relative level of skills as measured by $\ln \left(H_{t, s i} / H_{t, s j}\right)$ increases if:

(a) $\delta$ increases, because an increase in $\delta$ enhances and stimulates the accumulation of private knowledge $A_{t}$ which in turn enhance human capital accumulation $H_{t, s}$ as can be observed from equation (10) and (12);

(b) $\xi$ increases, because an increase in $\xi$ enhances and stimulates the accumulation of private knowledge $A_{t}$ as can be observed from equation (10);

(c) Bincreases, since from equation (3) it can be seen that an increase in $\beta$ leads to a higher rate of human capital accumulation. This increased human capital accumulation leads in turn to a faster increase of skill-biased technical change through the effects defined in equation (10);

(d) rincreases, because an increase in the return to physical capital stimulates investment, which enhances the accumulation of skills through the complementarity between skills and physical capital, as can be seen from equation (2);

(e) $\quad$ and $\sigma$ decrease, since present consumption is valued higher than future consumption, following the properties of equation (1). This leads to less need for skills, and hence the private investment in skills will fall. Lower private investment leads to less dispersion over time; and finally and most importantly

(f) $\tau$ decreases. This can be proven by the following expression and is a quite straightforward result, since an increase in capital income taxes decreases the amount invested in the accumulation of private knowledge leading to the skill bias, while leading to an increase in the amount invested in the accumulation of neutral public knowledge, i.e. 


$$
\frac{\partial \ln \left(H_{t, s_{i}} / H_{t, s_{j}}\right)}{\partial \tau}=\frac{-\left(s_{i}-s_{j}\right) \delta r t}{(1-\xi+\delta)(1-\beta) \sigma}<0
$$

This completes the investigation of Proposition 1.

This result shows that there is to some extent scope for the government to reduce the short=-run level effects of skill-biased technical change which are prevalent in the private sector. However, as noted above there remains a long-run bias in human capital growth rates in favor of relatively high-skilled individuals.

However, recently, as noted by e.g. Muysken and Ter Weel (1999) and Acemoglu (1998), the supply of relatively high-skilled labor increased in a dramatic fashion, while the wage premium or reward for this high-skilled labor increased in an even more dramatic way. This process of socalled directed technical change in which the direction of technical change is driven by the supply and availability of a particular level of labor has led and is leading to a further process and development of (wage) dispersion resulting in (wage) inequality in our Western societies. Government intervention by means of providing a 'public threshold level' of knowledge embodied in every single individual is therefore becoming increasingly important. The shift in the accumulation of private knowledge can be modeled by dividing the labor force in so-called 'haves' and 'have-nots', with regard to the level of skills needed to be part of the working labor force, as follows

$$
\dot{H}_{t, s}=A_{t}^{\max (s-\bar{s}, 0)} u_{s} H_{t, s}^{\beta} B_{t}^{\gamma}-\mu H_{t, s}
$$

which states that individuals have to embody a certain minimum or threshold level of skills $\bar{S}$, to profit from private knowledge accumulation. If their skill level is below this threshold level $\bar{s}$ they cannot enhance their skills by means of private knowledge accumulation. Hence, there is a strong case for the government to intervene in this process and to provide education and training to guarantee that the (overall) level of skills is sufficiently high. However, another problem of this trend is, that it is increasing over time, i.e. 


$$
\frac{\partial \bar{s}}{\partial t}>0
$$

frustrating government's efforts to enhance skills.

Government policies to enhance the position of relatively low-skilled workers should therefore be 'skill-biased' in the sense that it should aim at improving the position of relatively low-skilled workers. The way the effects of government intervention is modeled in this framework does suggest that efforts made by the government to distribute skills and therefore income more equally among individuals are neutral: every single individual profits, ceteris paribus, in the same manner from $\gamma B_{t}$. This knowledge, provided through a 'public basin' of knowledge, accessible for every single individual reduces the skill-bias, but only once; over time the bias will again increase. Therefore, government policies have to be effective both in the long run and induce a 'skill-bias' in order for relatively low-skilled individuals, like individuals $s_{j}$ in the example above, to profit more from the effort made by the government. 


\section{Concluding Remarks}

This paper has reviewed the literature on growth extensively and has provided a unique framework in which skill-biased technical change is explained by means of private investments in knowledge among firms. The investment in knowledge among firms is biased towards relatively skilled individuals because their ability to acquire this knowledge is assumed to be higher. This engine of growth leads to large levels of dispersion in wage income and human capital embodiment. On the other hand, accumulation of public knowledge leads to an unbiased or neutral increase in wage income and human capital embodiment.

This framework stresses the need for continuous government intervention to reduce the ongoing dispersion in human capital formation induced by skill-biased technical change. Moreover, the endogenous decision of individuals to school themselves proves not to be sufficient to deal with skill-biased technical change in a comprehensive manner. 


\section{References}

Acemoglu, D. (1998), Why Do New Technologies Complement Skills? Directed Technical Change and Wage Inequality, Quarterly Journal of Economics, vol. 113, no. 4, pp. 10551089.

Acemoglu, D. (1999), Patterns of Skill Premia, NBER Working Paper 7018, National Bureau of Economic Research, Cambridge MA.

Aghion, P. and P. Howitt (1992), A Model of Growth through Creative Destruction, Econometrica, vol. 60, no. 2, pp. 323-351.

Aghion, P. and P. Howitt (1998a), Endogenous Growth Theory, MIT Press, Cambridge MA.

Aghion, P. and P. Howitt (1998b), On the Macroeconomic Effects of Major Technological Change, in: Helpman, E. (ed.) General Purpose Technologies and Economic Growth, MIT Press, Cambridge MA.

Arrow, K. J. (1962), The Economic Implications of Learning by Doing, Review of Economic Studies, vol. 29, pp. 155-73.

Autor, D. H., L. F. Katz and A. B. Krueger (1998), Computing Inequality: How Computers Have Changed the Labor Market, Quarterly Journal of Economics, vol. 113, no. 4, pp. 11691214.

Azariadis, C. and A. Drazen (1990), Threshold Externalities in Economic Development, Quarterly Journal of Economics, vol. 105, no. 3, pp. 501-526.

Baldwin, J. R., B. Diverty and J. Johnson (1995), Success, Innovation, Technology and Human Resource Strategies an Interactive System, Paper presented at the conference on the effects of technology and innovation on firm performance and employment, Washington DC.

Barro, R. J. and X. Sala-I-Martin (1995), Economic Growth, McGraw-Hill, New York.

Bartel, A. and N. Sicherman (1995), Technological Change and the Skill Acquisition of Young Workers, NBER Working Paper 5107, National Bureau of Economic Research, Cambridge MA.

Becker, G. S., K. M. Murphy and R. Tamura (1990), Human Capital, Fertility and Economic Growth, Journal of Political Economy, vol. 98, no. 1, pp. 13-37.

Bell, B. D. (1996), Skill-Biased Technical Change and Wages: Evidence from a Longitudinal Data Set, Institute of Economics and Statistics, University of Oxford, mimeo.

Bellman, L. and T. Boeri (1995), Internal and External Creative Destruction: Determinants of Changes of Employment and Productivity, Paper presented at the conference on the effects of technology and innovation on firm performance and employment, Washington DC.

Bénabou, R. (1996), Inequality and Growth, in: Bernanke, B. S. and J. Rotemberg (eds.), NBER Macroeconomics Annual, vol. 11, The MIT Press, Cambridge MA, pp. 11-74.

Berman, E., J. Bound and S. Machin (1998), Implications of Skill-Biased Technological Change: International Evidence, Quarterly Journal of Economics, vol. 113, no. 4, pp. 1245-1279.

Bound, J. and G. Johnson (1992), Changes in the Structure of Wages in the 1980s: An Evaluation of Alternative Explanations, American Economic Review, vol. 82, no. 2, pp. 371-392.

Bresnahan, T. and A. Gambardella (1998), The Division of Inventive Labor and the Extent of the Market, in: E. Helpman (ed.), General Purpose Technologies and Economic Growth, 
MIT Press, Cambridge MA.

Bruinshoofd, W. A., H. Hollanders and B. J. ter Weel (1999), Knowledge Spillovers and Wage Inequality: An Empirical Investigation of Knowledge-Skill Complementarity, MERIT Research Memorandum 99-008, Maastricht University, Maastricht.

Bruinshoofd, W. A. and B. J. ter Weel (1998), Skill-Biased Technical Change: On Wages and Technology in the Netherlands, MERIT Research Memorandum 98-025, Maastricht University, Maastricht.

Chennells, L. and J. van Reenen (1997), Technical Change and Earnings in British Establishments, Economica, vol. 64, pp. 587-604.

Davis, D. R. and T. A. Reeve (1997), Human Capital, Unemployment and Relative Wages in a Global Economy, NBER Working Paper 6133, National Bureau of Economic Research, Cambridge MA.

Denny M. and M. Fuss (1983), The Effects of Factor Prices and Technological Change on the Occupational Demand for Labour: Evidence from Canadian Telecommunications, Journal of Human Resources, vol. XVII, no. 2, pp. 161-176.

DiNardo, J. E. and J.-S. Pischke (1997), The Returns to Computer use Revisited: Have Pencils Changed the Wage Structure Too?, Quarterly Journal of Economics, vol. 112, no. 1, pp. 291-303.

Doms, M., T. Dunne and M. Roberts (1997), Workers, Wages and Technology, Quarterly Journal of Economics, vol. 112, no. 1, pp. 253-290.

Dosi, G., C. Freeman, R. R. Nelson, G. Silverberg and L. Soete (eds.) (1988), Technical Change and Economic Theory, Pinter, London.

Entorf, H. and F. Kramarz (1997), Does Unmeasured Ability Explain the Higher Wages of New Technology Workers, European Economic Review, vol. 41, pp. 1489-1509.

Francois, J.-F. and D. Nelson (1998), Trade, Technology, and Wages: General Equilibrium Mechanics, Economic Journal, vol. 108, no. 4, pp. 1483-1499.

Goldin, C. and L. F. Katz (1998), The Origins of Technology-Skill Complementarity, Quarterly Journal of Economics, vol. 113, no. 3, pp. 693-732.

Griliches, Z. (1969), Capital-Skill Complementarity, The Review of Economics and Statistics, vol. 51, no. 4, pp. 465-468.

Grossman, G.M. and E. Helpman (1989), Product Development and International Trade, Journal of Political Economy, vol. 97, no. 6, pp. 1261-83.

Grossman, G.M. and E. Helpman (1990), Comparative Advantage and Long Run Growth, American Economic Review, vol. 80, pp. 796-815.

Grossman, G.M. and E. Helpman (1991a), Quality Ladders in the Theory of Growth, Review of Economic Studies, vol. 58, pp. 43-61.

Grossman, G.M. and E. Helpman (1991b), Quality Ladders and Product Cycles, Quarterly Journal of Economics, vol. 106, pp. 557-86.

Harberger, A. (1998), A Vision of the Growth Process, American Economic Review, vol. 88, no. 1, pp. 1-32.

Harris, R. G. (1998), The Internet as a GPT: Factor Market Implications, in: E. Helpman (ed.), General Purpose Technologies and Economic Growth, MIT Press, Cambridge MA.

Haskel, J. E. and M. J. Slaughter (1998), Does the Sector Bias of Skill-Biased Technical Change Explain Changing Wage Inequality?, NBER Working Paper 6565, National Bureau of Economic Research, Cambridge MA.

Heckman, J., L. Lochner and C. Taber (1998), Explaining Rising Wage Inequality: Explorations 
with a Dynamic General Equilibrium Model of Labor Earnings with Heterogenous Agents, NBER Working Paper 6384, National Bureau of Economic Research, Cambridge MA.

Heckman, J. and G. Sedlacek (1985), Heterogeneity, Aggregation and Market Wage Functions: An Empirical Model of Self-Selection in the Labor Market, Journal of Political Economy, vol. 98, no. 4, pp. 1077-1125.

Helpman, E. and M. Trajtenberg (1998a), Diffusion of General Purpose Technologies, in: E. Helpman (ed.), General Purpose Technologies and Economic Growth, MIT Press, Cambridge MA.

Helpman, E. and M. Trajtenberg (1998b), A Time to Sow and a Time to Reap: Growth Based on General Purpose Technologies, in: E. Helpman (ed.), General Purpose Technologies and Economic Growth, MIT Press, Cambridge MA.

Hildreth, A. (1998), Rent-Sharing and Wages: Product Demand or Technology Driven Premia?, Economics of Innovation and New Technology, vol. 5, pp. 199-226.

Hollanders, H., L. Soete and B. J. ter Weel (1999), World Knowledge Report, Edward Elgar, London (forthcoming 1999).

Hollanders, H. and B. J. ter Weel (1998), Skill-Biased Technological Change in an Endogenous Growth Model, MERIT Research Memorandum 98-019, Maastricht University, Maastricht.

Hollanders, H. and B. J. ter Weel (1999), Growth, Knowledge and Skills: Technical Change and Low-Development Traps, MERIT mimeo.

Howitt, P. (1998), Measurement, Obsolescence, and General Purpose Technologies in: E. Helpman (ed.), General Purpose Technologies and Economic Growth, MIT Press, Cambridge MA.

Jones, C.I. (1995a), R\&D-Based Models of Economic Growth, Journal of Political Economy, vol. 103 , no. 4 , pp. $759-784$.

Jones, C.I. (1995b), Time Series Tests of Growth Models, Quarterly Journal of Economics, vol. CX, pp. 495-525.

Juhn, C., K. Murphy and B. Pierce (1993), Wage Inequality and the Rise in Returns to Skill, Journal of Political Economy, vol. 101, no. 2, pp. 410-442.

Katz, L. F. and K. M. Murphy (1992), Changes in Relative Wages, 1963-1987: Supply and Demand Factors, Quarterly Journal of Economics, vol. 107, no. 1, pp. 35-78.

King, M.A. and M.H. Robson (1993), A Dynamic Model of Investment and Endogenous Growth, Scandinavian Journal of Economics, vol. 95, no. 4, pp. 445-66.

Krueger, A. B., 1993, How Computers Have Changed the Wage Structure: Evidence from Micro Data 1984-1989, Quarterly Journal of Economics, vol. CVIII, no. 1, pp. 33-60.

Krugman, P. (1995), Technology, Trade and Factor Prices, NBER Working Paper 5355, National Bureau of Economic Research, Cambridge MA.

Lipsey, R. G., C. Bekar and K. Carlaw (1998a), What Requires Explanation?, in: E. Helpman (ed.), General Purpose Technologies and Economic Growth, MIT Press, Cambridge MA.

Lipsey, R. G., C. Bekar and K. Carlaw (1998b), The Consequences of Changes in GPTs, in: E. Helpman (ed.), General Purpose Technologies and Economic Growth, MIT Press, Cambridge MA.

Lucas, R.E. Jr. (1988), On the Mechanics of Economic Development, Journal of Monetary Economics, vol. 22, pp. 3-42.

Lucas, R.E. Jr. (1993), Making a Miracle, Econometrica, vol. 61, pp. 251-72. 
Machin, S. and J. Van Reenen (1998), Technology and Changes in Skill Structure: Evidence from Seven OECD Countries, Quarterly Journal of Economics, vol. 113, no. 4, pp. 12151244.

McDonald, I. M. and R. M. Solow (1985), Wages and Employment in a Segmented Labor Market, Quarterly Journal of Economics, vol. 100, no. 4, pp. 1115-1141.

Meghir, C. and E. Whitehouse (1996), The Evolution of Wages in the United Kingdom: Evidence from Micro Data, Journal of Labor Economics, vol. 14, no. 1, pp. 1-25.

Murphy, K. M., W. C. Riddell and P. M. Romer (1998), Wages, Skills and Technology in the United States and Canada, in: E. Helpman (ed.), General Purpose Technologies and Economic Growth, MIT Press, Cambridge MA.

Muysken, J. and B. J. ter Weel (1999), Overeducation and Crowding Out of Low-Skilled Workers, in Borghans, L. and A. de Grip (eds,), Skill Utilisation and Bumping Down, Edward Elgar: London (forthcoming Spring 1999).

Nelson, R. R. and S. Winter (1982), An Evolutionary Theory of Economic Change, Harvard University Press, Cambridge MA.

Nickell, S. J. and B. D. Bell (1995), The Collapse in Demand for the Unskilled and Unemployment across the OECD, Oxford Review of Economic Policy, vol. 11, no. 1, pp. 40-62.

Nickell, S. J. and B. D. Bell (1996), Changes in the Distribution of Wages and Unemployment in OECD Countries, American Economic Review, vol. 86, no. 2, pp. 302-308.

OECD (1998), Employment Outlook, OECD Paris.

Prescott, E. C. and J. H. Boyd (1987), Dynamic Coalitions: Engines of Growth, American Economic Review, vol. 77, no. 2, pp. 63-67.

Rebelo, S. (1991), Long-Run Policy Analysis and Long-Run Growth, Journal of Political Economy, vol. 99, no. 3, pp. 500-21.

Redding, S. (1996), The Low-Skill, Low-Quality Trap: Strategic Complementarities between Human Capital and R\&D, Economic Journal, vol. 106, no. 2, pp. 458-470.

Romer, P. M. (1986), Increasing Returns and Long-Run Growth, Journal of Political Economy, vol. 94, no. 5, pp. 1002-37.

Romer, P. M. (1987), Growth Based on Increasing Returns Due to Specialization, American Economic Review, vol. 77, no. 2, pp. 56-62.

Romer, P. M. (1990), Endogenous Technological Change, Journal of Political Economy, vol. 98, no. 5, part 2, pp. s71-s102.

Romer, P. M. (1993), Implementing a National Technology Strategy with Self-Organising Industry Investment Boards, Brooking Papers on Economic Activity, pp. 345-390.

Rosenberg, N. (1998), Chemical Engineering as a General Purpose Technology, in: E. Helpman (ed.), General Purpose Technologies and Economic Growth, MIT Press, Cambridge MA.

Schneider, J. and T. Ziesemer (1995), What's New and What's Old in New Growth Theory? Endogenous Technology, Microfoundations and Growth Rate Predictions - A Critical Overview, Zeitschrift für Wirtschaft- und Sozialwissenschaften, Vol. 115, No. 3, pp. 144.

Segerstrom, P. S., T. Anant and E. Dinopoulos (1990), A Schumpeterian Model of the Product Life Cycle, American Economic Review, vol. 80, pp. 1077-1092.

Soete, L. and B. J. ter Weel (1999), Innovation, Knowledge Creation and Technology Policy: The Case of the Netherlands, De Economist, vol. 147 (forthcoming June 1999).

Stokey, N. (1988), Learning by Doing and the Introduction of New Goods, Journal of Political 
Economy, vol. 96, no. 4, pp. 701-47.

Uzawa, H. (1965), Optimum Technical Change in an Aggregative Model of Economic Growth, International Economic Review, Vol. 6, No. 1, pp. 18-31.

Vaniniomaki, J. and S. Laaksonen (1995), Inter-industry Wage Differentials in Finland: Evidence from Longitudinal Census Data for 1975-85, Labour Economics, vol. 2, no. 2, pp. 161-173.

Verspagen, B. (1992), Endogenous Innovation in Neoclassical Growth Model: A Survey, Journal of Macroeconomics, vol. 14, no. 4, pp. 631-62.

Weder, R. and H. G. Grubel (1993), The New Growth Theory and Coasean Economics: Institutions to Capture Externalities, Welwirtschaftliches Archiv, vol. 129, pp. 488-513.

Wood, A. (1998), Globalisation and the Rise in Labour Market Inequalities, Economic Journal, vol. 108, no. 4, pp.1463-1482.

Yang, X. and J. Borland (1991), A Microeconomic Mechanism for Economic Growth, Journal of Political Economy, vol. 99, no. 3, pp. 460-82.

Young, A. (1991), Learning by Doing and the Dynamic Effects of International Trade, Quarterly Journal of Economics, vol. 106, pp. 369-405.

Young, A. (1993a), Invention and Bounded Learning by Doing, Journal of Political Economy, vol. 101, no. 3, pp. 443-72.

Young, A. (1993b), Substitution and Complementarity in Endogenous Innovation, Quarterly Journal of Economics, vol. 108, pp. 775-807.

Ziesemer, T. (1991), Human Capital, Market Structure and Taxation in a Growth Model with Endogenous Technical Progress, Journal of Macroeconomics, vol. 13, pp. 47-68. 


\section{Appendix A. Consumer optimum}

Consumers maximize life-time utility with respect to the budget constraint and their human capital accumulation function. This results in the Hamiltonian $\Omega$, which is defined as:

$$
\Omega=\left(\frac{C_{t, s}^{1-\sigma}-1}{1-\sigma}\right) e^{-\rho t}+\lambda_{1}\left(A_{t}^{s} u_{s} H_{t, s}^{\beta} B_{t}^{\gamma}-\mu H_{t, s}\right)+\lambda_{2}\left((1-\tau) r_{t} K_{t, s}+(1-\tau) w_{t}\left(1-u_{s}\right) H_{t, s}-C_{t, s}\right)
$$

The control variables in the Hamiltonian are $C_{t, s}$ and $u_{s}$. Taking partial derivatives with respect to the control variables gives us equations (A.1) and (A.2):

$$
\begin{gathered}
\frac{\partial \Omega}{\partial C_{t, s}}=C_{t, s}^{-\sigma} e^{-\rho t}-\lambda_{2}=0 \\
\frac{\partial \Omega}{\partial u_{s}}=\lambda_{1} A_{t}^{s} H_{t, s}^{\beta} B_{t}^{\gamma}-\lambda_{2}(1-\tau) w_{t} H_{t, s}=0
\end{gathered}
$$

Taking partial derivatives with respect to the state variables $H_{t, s}$ and $K_{t, s}$ gives the following pair of differential equations:

$$
\begin{gathered}
\dot{\lambda}_{1}=-\frac{\partial \Omega}{\partial H_{t, s}}=-\lambda_{1}\left(\beta A_{t}^{s} u_{s} H_{t, s}^{\beta-1} B_{t}^{\gamma}-\mu\right)-\lambda_{2}(1-\tau) w_{t}\left(1-u_{s}\right) \\
\dot{\lambda}_{2}=-\frac{\partial \Omega}{\partial K_{t, s}}=-\lambda_{2}(1-\tau) r_{t}
\end{gathered}
$$

Dividing equation (A.4) by $\lambda_{2}$, taking growth rates of equation (A.1) and equating the results gives us the solution for individual $I$ with skill level $s$. This is a standard Euler equation:

$$
\hat{C}_{t, s}=\left(\frac{(1-\tau) r-\rho}{\sigma}\right)
$$


From now on we drop the subscript $t$ for the rental rate $r$, as this rental rate is constant in our steady state analysis.

Dividing equation (A.3) by $\lambda_{1}$, making use of equation (A.2) and then expressing this in growth rates gives us the solution for $\hat{H}_{t, s}$ :

$$
\hat{H}_{t, s}=\frac{s \hat{A}_{t}+\gamma \hat{B}_{t}}{1-\beta}
$$

Dividing equation (A.4) by $\lambda_{2}$ and expressing equation (A.2) in growth rates results in the growth rates for costate variables which satisfy:

$$
\begin{gathered}
\hat{\lambda}_{2}=-(1-\tau) r \\
\hat{\lambda}_{1}=\hat{\lambda}_{2}+\hat{w}_{t}=-(1-\tau) r+\hat{w}_{t}
\end{gathered}
$$

Dividing equation (A.3) by $\lambda_{1}$, making use of equation (A.2) and solving for $u_{s}$, gives us the following expression for the amount of time consumers spend on human capital accumulation:

$$
u_{s}=\frac{\hat{H}_{t, s}+\mu}{(1-\beta)\left(\hat{H}_{t, s}+\mu\right)-\hat{\lambda}_{1}+\mu}
$$

Making use of equation (A.6), (A.7) and (A.8), and assuming no depreciation of human capital $(\mu=0)$, this expression can be rewritten as

$$
u_{s}=\frac{s \hat{A}_{t}+\gamma \hat{B}_{t}}{(1-\beta)\left(s \hat{A}_{t}+\gamma \hat{B}_{t}+(1-\tau) r-\hat{w}_{t}\right)}
$$




\section{Appendix B}

From equation (A.6), we can in a straightforward way calculate the solution for the level of human capital $H_{t, s}$ :

$$
H_{t, s}=H_{0, s} e^{\left(s \hat{A}_{t}+\gamma \hat{B}_{t}\right) t /(1-\beta)}
$$

Assuming that all individuals start with the same level of human capital $H_{0, s}=1$, the overall level of human capital can be calculated - by integrating over equation (B.1) for all individuals - as:

$$
H_{t}=\int_{0}^{1} H_{t, s} d s=\int_{0}^{1} e^{\left(s \hat{A}_{t}+\gamma \hat{B}_{t}\right) t /(1-\beta)} d s
$$

Solving this integral and substituting $s=0$ and $s=1$ leads to the solution for $H_{t}$ :

$$
H_{t}=\frac{(1-\beta)\left[e^{\left(\hat{A}_{t}+\gamma \hat{B}_{t}\right) t /(1-\beta)}-e^{\left(\gamma \hat{B}_{t}\right) t /(1-\beta)}\right]}{t \hat{A}_{t}}
$$

This expression gives us the overall level of human capital at time $t$. 


\section{Appendix C. Firm optimum}

The Hamiltonian for the firm's profit maximization problem is defined as:

$$
\Pi=K_{t}^{\alpha}\left(A_{t} \int_{0}^{1}\left((1-\phi)\left(1-u_{s}\right)\right) H_{t, s} d s\right)^{v}-r K_{t}-w_{t} \int_{0}^{1}\left(1-u_{s}\right) H_{t, s} d s+\lambda_{3}\left(\int_{0}^{1}\left(\phi\left(1-u_{s}\right)\right) H_{t, s} d s\right)^{\delta} A_{t}^{\xi}
$$

The amount of human capital available to the firm can be found by solving:

$$
\int_{0}^{1}\left(1-u_{s}\right) H_{t, s} d s=\int_{0}^{1}\left(\frac{-((1-\beta)+\beta s) \hat{A}_{t}-\beta \gamma \hat{B}_{t}+(1-\beta)(1-\tau) r}{(1-\beta)\left(-(1-s) \hat{A}_{t}+\gamma \hat{B}_{t}\right)+(1-\beta)(1-\tau) r}\right) e^{\left(s \hat{A}_{t}+\gamma \hat{B}_{t}\right) t /(1-\beta)} d s
$$

which leads to the following solution

$$
\frac{-\beta\left(e^{\left(\frac{\hat{A}_{t}+\gamma \hat{B}_{t}}{1-\beta}\right) t}-e^{\left(\frac{\gamma \hat{B}_{t}}{1-\beta}\right) t}\right)}{\hat{A}_{t} t}+\frac{\left(-\hat{A}_{t}+(1-\tau) r\right)}{1-\beta}\left[\sum_{n=1}^{n=\infty}\left(\frac{(n-1) !(1-\beta)^{n}}{\hat{A}_{t} t^{n}\left(-(1-s) \hat{\left.A_{t}+\gamma \hat{B}_{t}+(1-\tau) r\right)^{n}}\right)} e^{\left(\frac{s \hat{A}_{t}+\gamma \hat{B}_{t}}{1-\beta}\right) t}\right]_{s=0}^{s=1}\right.
$$

It can be shown that this expression has a finite solution. For convenience, this is defined as $H_{t, f}$.

The Hamiltonian can now be rewritten as

$$
\Pi=K_{t}^{\alpha}\left(A_{t}(1-\phi) H_{t, f}\right)^{v}-r K_{t}-w_{t} H_{t, f}+\lambda_{3}\left(\phi H_{t, f}\right)^{\delta} A_{t}^{\xi}
$$

The control variables are $K_{t}, H_{t, f}$ and $\phi$. Taking partial derivatives with respect to the control variables gives equations (C.2) to (C.4):

$$
\frac{\partial \Pi}{\partial K_{t}}=\alpha(1-\phi)^{v} K_{t}^{\alpha-1} A_{t}^{v} H_{t, f}^{v}-r=0
$$




$$
\begin{gathered}
\frac{\partial \Pi}{\partial H_{t, f}}=v(1-\phi)^{v} K_{t}^{\alpha} A_{t}{ }^{v} H_{t, f}^{v-1}-w_{t}+\lambda_{3} \delta \phi^{\delta} A_{t}^{\xi} H_{t, f}^{\delta-1}=0 \\
\frac{\partial \Pi}{\partial \phi}=-v(1-\phi)^{v-1} K_{t}^{\alpha} A_{t}^{v} H_{t, f}^{v}+\lambda_{3} \delta \phi^{\delta-1} A_{t}^{\xi} H_{t, f}^{\delta}=0
\end{gathered}
$$

Taking partial derivatives with respect to the state variable $A_{t}$ gives the following differential equation for $\lambda_{3}$ :

$$
\dot{\lambda}_{3}=-\frac{\partial \Pi}{\partial A_{t}}=-v(1-\phi)^{v} K_{t}^{\alpha} A_{t}^{v-1} H_{t, f}^{v}-\lambda_{3} \xi \phi^{\delta} A_{t}^{\xi-1} H_{t, f}^{\delta}
$$

Furthermore, the change in private knowledge is given by:

$$
\dot{A_{t}}=\left(\phi H_{t, f}\right)^{\delta} A_{t}^{\xi}
$$

Dividing (C.6) by $A_{t}$ and taking growth rates, gives the following relation between the growth rates of human capital and private knowledge:

$$
\hat{H}_{t, f}=\left(\frac{1-\xi}{\delta}\right) \hat{A}_{t}
$$

Rewriting (C.2) in growth rates, and making use of (C.7), gives a relation between the growth rates of physical capital and private knowledge:

$$
\hat{K}_{t}=\left(\frac{1+\delta-\xi}{\delta}\right) \hat{A}_{t}
$$

Using (C.4) to rewrite (C.3) in growth rates, and making use of (C.7) and (C.8) leads to the conclusion that wages grow with the same rate as private knowledge:

$$
\hat{w}_{t}=\hat{A}_{t}
$$

The part of the human capital stock available to firms that is devoted to the production of new 
knowledge is equal to:

$$
\phi=\frac{\delta}{\left(\frac{1-\xi}{\delta}\right)-\delta+\xi}
$$

It can be shown that $0<\phi<1$. 


\section{Appendix D}

The accumulation of the stock of physical capital $K_{t}$ equals the sum of the individual capital stocks:

$$
\dot{K}_{t}=\int_{0}^{1} \dot{K}_{t, s} d s
$$

Making use of equations (2), (4), the definition for $H_{t, f}$

$$
H_{t, f}=\int_{0}^{1}\left(1-u_{s}\right) H_{t, s} d s
$$

and the fact that

$$
K_{t}=\int_{0}^{1} K_{t, s} d s
$$

equation (D.1) can easily be rewritten as

$$
\dot{K}_{t}=(1-\tau) r K_{t}+(1-\tau) w_{t} H_{t, f}-e^{((1-\tau) r-\rho) t / \sigma}
$$

The steady-state relations between the growth rates of $K_{t}, H_{t}$ and $A_{t}$, as expressed in equations (C.7) and (C.8), leads to the conclusion that the growth rate of the physical capital stock equals that of consumption

$$
\hat{C}_{t}=\hat{K}_{t}=\frac{(1-\tau) r-\rho}{\sigma}
$$

